\title{
An Archaeological Survey of the Proposed Retama/Selma Monopole Project
}

\author{
Bradley J. Vierra \\ Center for Archaeological Research \\ Brett A. Houk \\ Center for Archaeological Research \\ Diane A. Cargill \\ Center for Archaeological Research
}

Follow this and additional works at: https://scholarworks.sfasu.edu/ita

Part of the American Material Culture Commons, Archaeological Anthropology Commons, Environmental Studies Commons, Other American Studies Commons, Other Arts and Humanities Commons, Other History of Art, Architecture, and Archaeology Commons, and the United States History Commons

Tell us how this article helped you.

This Article is brought to you for free and open access by the Center for Regional Heritage Research at SFA ScholarWorks. It has been accepted for inclusion in Index of Texas Archaeology: Open Access Gray Literature from the Lone Star State by an authorized editor of SFA ScholarWorks. For more information, please contact cdsscholarworks@sfasu.edu. 


\section{An Archaeological Survey of the Proposed Retama/Selma Monopole Project \\ Creative Commons License \\ (c) (i) (8)}

This work is licensed under a Creative Commons Attribution-NonCommercial 4.0 International License 


\section{An Archaeological Survey of the Proposed Retama/Selma Monopole Project}

Bradley J. Vierra, Brett A. Houk, and Diane A. Cargill

Robert J. Hard and C. Britt Bousman

Principal Investigators

Ccopyright

Center for Archaeological Research

The University of Texas at San Antonio

Archaeological Survey Report, No. 274

1998 
The following information is provided in accordance with the General Rules of Practice and Procedure, Chapter 41.11 (Investigative Reports), Texas Antiquities Committee:

1. Type of investigation: Survey

2. Project name: Retama/Selma Monopole Project

3. County: Guadalupe

4. Principal investigators: Robert J. Hard and C. Britt Bousman

5. Name and location of sponsoring agency: Southwestern Bell Wireless, 18610 Blanco Rd., San Antonio, Texas 78258

6. Texas Antiquities Permit No.: n/a

7. Published by the Center for Archaeological Research, The University of Texas at San Antonio, 6900 N. Loop 1604 W., San Antonio, Texas 78249-0658, 1998

A list of publications offered by the Center for Archaeological Research is available. Call (210) 458-4378; write to the Center for Archaeological Research, The University of Texas at San Antonio, 6900 N. Loop 1604 W., San Antonio, Texas 78249-0658; e-mail to car@lonestar.utsa.edu; or visit CAR's web site at http://www.csbs.utsa.edu/research/car/index.htm. 


\begin{abstract}
The Center for Archaeological Research (CAR) of The University of Texas at San Antonio conducted an archaeological survey of the proposed Retama/Selma Monopole Project for Southwestern Bell Wireless. The investigations included two backhoe trenches, four shovel tests, and a 100-percent pedestrian survey of the project area and access road. The backhoe trenches and shovel tests did not encounter any subsurface artifacts or features, but the pedestrian survey discovered a lithic scatter in the access road. This site, designated 41GU39, contains an Early Archaic component as evidenced by a Gower point. The artifacts appear to be confined to the surface and a 10-cm-thick plow zone. CAR recommends that the proposed project will have no adverse effect and that the sponsor be allowed to proceed as planned.
\end{abstract}




\section{Contents}

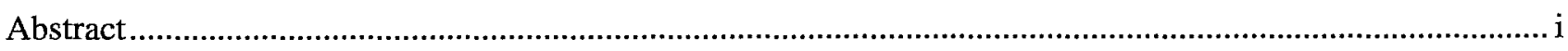

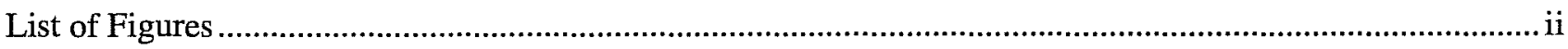

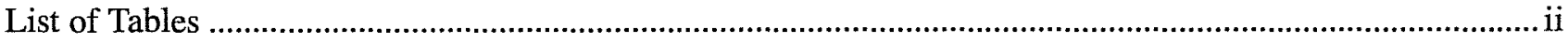

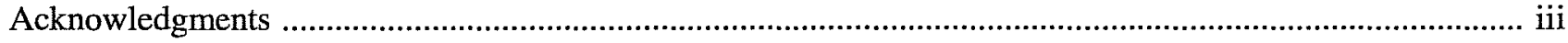

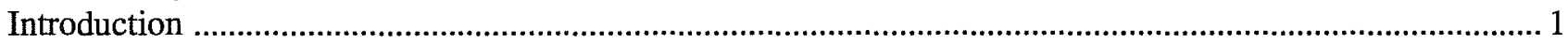

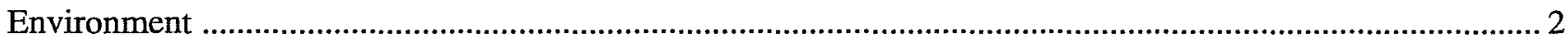

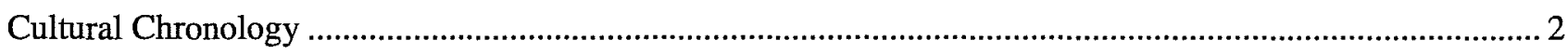

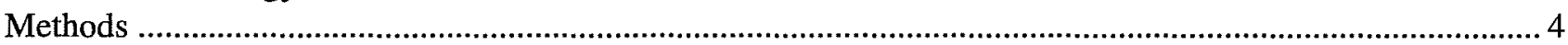

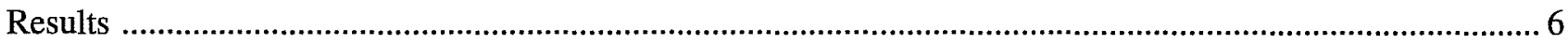

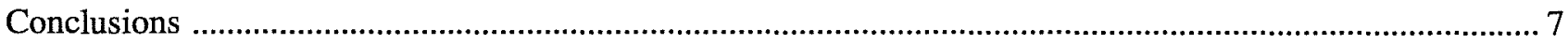

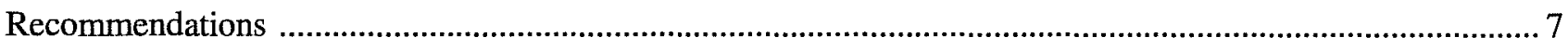

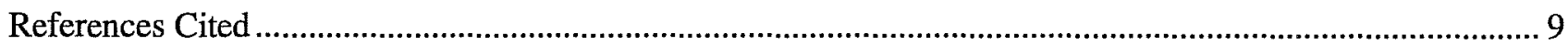

\section{Figures}

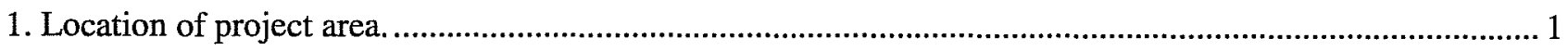

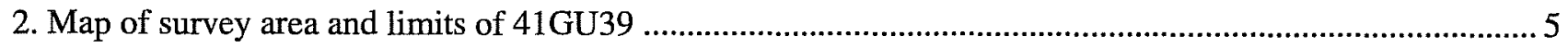

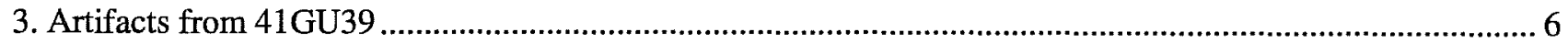

\section{Tables}

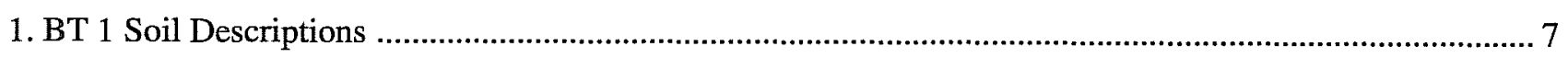

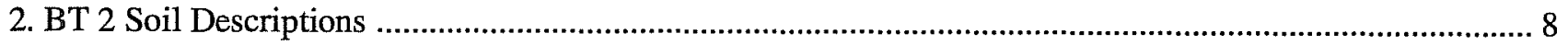




\section{Acknowledgments}

The authors would like to thank the following individuals for their roles in making this a successful project. Ms. Martha Arzate and Mr. C. R. Pope of Southwestern Bell Wireless us with the necessary construction plans, maps, and data. Mike Fulgham, of Wrightway Backhoe, expertly excavated our backhoe trenches. We would also like to thank C. Britt Bousman for examining the geomorphology of the project area, and Anthony Lyle for his role as field assistant during the survey. Mr. Herb Uecker of the Texas Historical Commission kindly consulted with us on the nature of the cultural resources in the project area and our recommendations. Finally, Mr. Charlie Sanchez and Garden Ridge North graciously provided us access to the property so that we could conduct our investigations. We would also like to acknowledge Bruce Moses and Marcie Renner for their drafting and editing, respectively. 


\section{Introduction}

On October 16, 1997, Southwestern Bell Wireless (SWBW) contracted the Center for Archaeological Research (CAR) of The University of Texas at San Antonio to conduct an archaeological survey of the proposed Retama/Selma Monopole Project area in Selma, Texas (Figure 1). SWBW proposes to construct a 61-m-high cellular phone tower approximately 200 m north of Cibolo Creek on FM 1518. The project area is adjacent to Bob White's Express, a business with a chain-link fence surrounding the property.

The project is permitted by the Federal Communications Commission and is therefore subject to
Section 106 review under the National Historic Preservation Act. Because the project area is located in an alluvial terrace of Cibolo Creek, the Texas Historical Commission (THC) notified SWBW in a letter dated October 8, 1997, that an archaeological survey of the project site was required.

The investigations were conducted on October 20, 1997. Robert J. Hard and C. Britt Bousman were coprincipal investigators, Brad Vierra was project archaeologist, and Tony Lyle was the field assistant. Brett A. Houk coordinated the implementation of the project. Mike Fulgham of Wrightway Backhoe operated the backhoe during the survey.

Figure 1. Project area location.

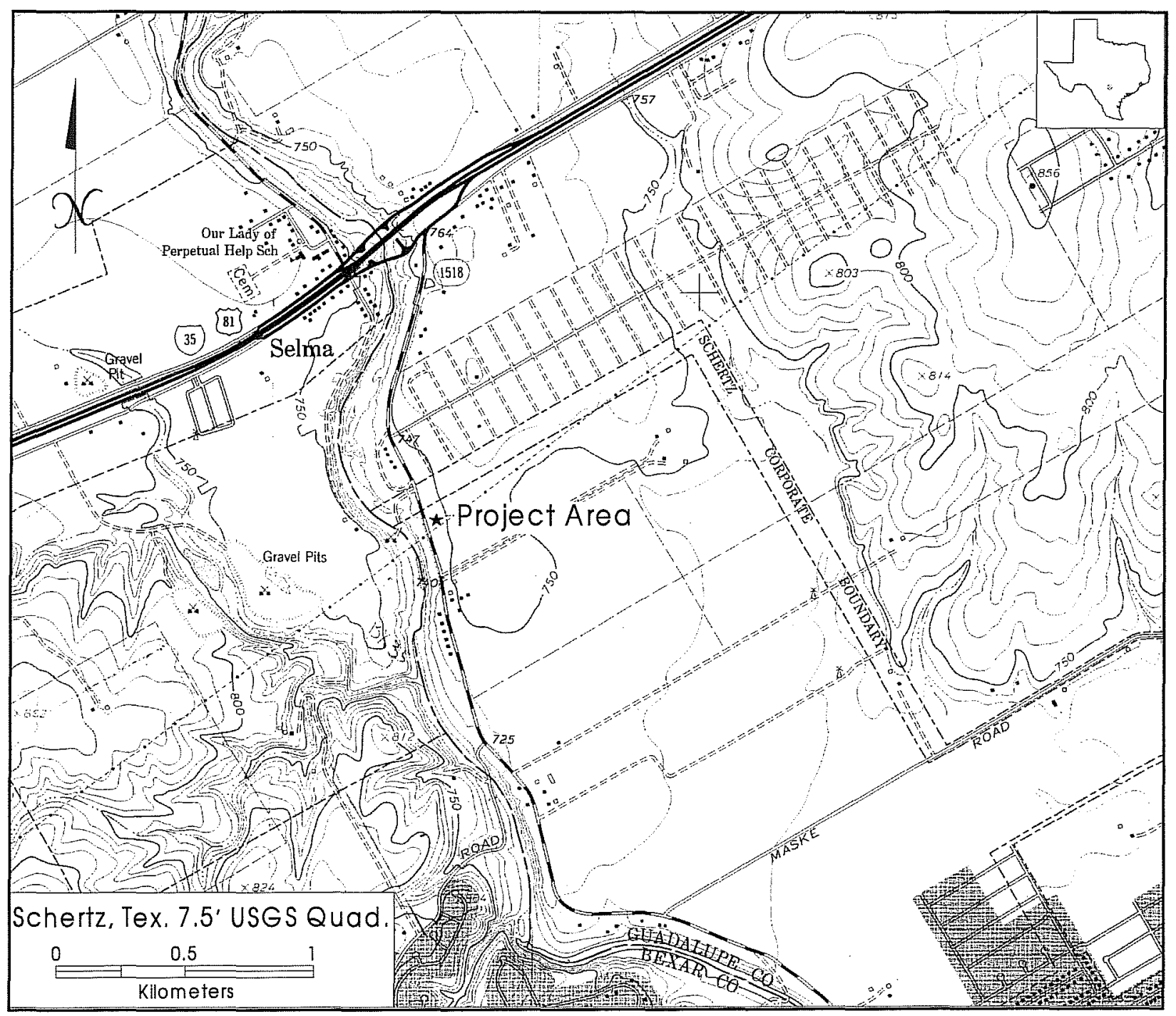


The proposed construction project involves the installation of a 6.7-m-deep, 2-m-wide foundation for the cellular phone tower monopole. Additionally, the construction of a small building adjacent to the monopole will involve the excavation of a $6.1-\mathrm{x}-3.5-\mathrm{m}$ area, approximately $0.6 \mathrm{~m}$ deep, for the building's foundation. Approximately $0.25 \mathrm{~m}$ of fill will be poured onto the existing ground surface over the course of a 6.1-m-wide access road to the tower and building complex. A chain-link fence will be installed around the perimeter of the building and access road.

\section{Environment}

The project area is located in extreme western Guadalupe County, near the junction with Comal and Bexar counties, $200 \mathrm{~m}$ north of Cibolo Creek at an elevation of $229 \mathrm{~m}$ (750 ft) above mean sea level. The project area is approximately $10 \mathrm{~m}$ above the modern channel of Cibolo Creek. The soils along this section of the creek are part of the Branyon-Barbarosa-Lewisville association and are characterized by deep, moderately well-drained to well-drained, clayey soils on stream terraces (Ramsey and Bade 1977). In the immediate project area, the soils are Lewisville silty clays which formed in ancient, calcareous, clayey alluvium (Ramsey and Blade 1977:23). They are generally deep, calcareous, and nearly level to gently sloping soils located on stream terraces (Ramsey and Bade 1977:23).

The project area is located in the Blackland Prairie, a narrow band of the coastal plain characterized by deep, clayey soils just east of the Balcones Escarpment. Prehistorically, this area was an important ecotone-the environmentally transitional area between the Edwards Plateau to the north and west and the prairies to the south and east (Collins 1995:366). The Blackland Prairie vegetational area is characterized by a mix of tall grass species (Collins and Ricklis 1994). Oak mottes are typically found in the upland areas, and larger stream riparian zones contain oak, pecan, walnut, hackberry, sumac, bald cypress, and cottonwood trees. Mesquite is common to higher stream terraces, but is also present in the deep soils of gentle upland slopes (Collins and Ricklis 1994). This area is included in the Texan biotic province defined by Blair (1950).
Blair (1950) identifies 49 species of mammals, 2 land turtles, 16 lizards, 39 snakes, and 23 amphibians within this province.

\section{Cultural Chronology}

Most researchers place Guadalupe County in the Central Texas archaeological region (Black 1989a; Collins 1995; Prewitt 1981). Our understanding of the prehistory of Central Texas is constantly changing as more sites are discovered and excavated. Researchers typically divide the 11,500 years of human occupation of the area into various periods representing major technological or cultural changes. The following chronology is based largely on recent revisions made by Collins and Ricklis (1994) and Collins (1995). Other frameworks are presented by Prewitt (1981), Black (1989b), and Turner and Hester (1993).

\section{Paleoindian}

The Paleoindian period in Central Texas spans approximately 3,000 years from $11,500-8800$ B.P. (Collins 1995). Two subperiods-Early Paleoindian (11,500-10,000 B.P.) and Late Paleoindian (10,0008800 B.P.)-have been identified. Lanceolate projectile points associated with the early subperiod are Clovis, Folsom, and Plainview. Those of the late subperiod include Golondrina, Angostura, Scottsbluff, and Meserve (Black 1989b). Artifacts from the Paleoindian period are commonly found on the surface as isolated finds; however, camp, quarry/stoneworking, kill, cache, ritual, and burial sites have been reported (Collins 1995).

Early Paleoindians have typically been described in the archaeological literature as nomadic, specialized "big game" hunters in pursuit of now-extinct Late Pleistocene fauna such as mammoth and Bison antiquus. With the extinction of these species, a specialized hunting strategy continued through the Late Paleoindian period, but the target of prey shifted to other large herbivores such as Bison bison and deer (Odocoileus). As more data on early Paleoindian subsistence is recovered, however, the perception of "big game" hunters is giving way to "well adapted, 
generalized hunters-gatherers with the technology to hunt big game but not the need to rely exclusively on it" (Collins 1995:382).

\section{Archaic}

The Archaic period in Central Texas spans approximately 7,500 years from 8800-1200/1300 B.P. (Collins 1995). Three subperiods-Early Archaic (8800-6000 B.P.), Middle Archaic (6000-4000 B.P.), and Late Archaic (4000-1200/1300 B.P.) - have been identified. Changes in projectile point styles, a more localized geographic distribution of artifacts, an increase in the number of sites, and the presence of burned rock scatters, hearths, and middens separate the Archaic from the Paleoindian period (Collins 1995).

\section{Early Archaic}

The Early Archaic period is characterized by Gower, Hoxie, Wells, Bell, Andice, Uvalde, Martindale, Baird, and Early Triangular projectile points (Collins and Ricklis 1994). Additional diagnostic artifacts from this subperiod include unifacial and bifacial Clear Fork tools, and the bifacial Guadalupe tool (Black 1989b; Collins 1995). While Early Archaic tools are found beyond Central Texas, implying "broad settlement patterns and resource utilization" (Trierweiler et al. 1995:31), a concentration of early Archaic components located close to the eastern and southern border of the Edwards Plateau along the Balcones Escarpment has been documented (Black 1989b; Collins 1995). One explanation for this apparent pattern focuses on the availability of water along the escarpment during an arid climatic interval (Black 1989b; McKinney 1981). Recovered subsistence remains demonstrate the exploitation of deer, small mammals, reptiles, amphibians, and fish. The intensified use of plant resources is indicated by the presence of cammus bulbs from earth ovens (Collins 1995). Early Archaic hunters and gatherers are considered to have been organized into small, highly mobile bands, with low population densities (Weir 1976).

\section{Middle Archaic}

The Middle Archaic is characterized by Nolan, Travis, Bulverde, Pedernales, Marshall, Williams, and Lange stemmed projectile points (Collins and Ricklis 1994). In comparison to the Early Archaic, the Middle Archaic is represented by increases in the number of sites, site size, and number of diagnostic artifact types (Collins and Ricklis 1994). Weir (1976) proposes that the observed increase in site density during this period was a direct result of increased population density.

Burned rock features including scatters, hearths, and middens are hallmarks of the Middle Archaic period in Central Texas (Collins 1995). The number of burned rock middens increases, and the maximum size and thickness of these features are reached during this period (Collins and Ricklis 1994). Several ideas regarding the function of burned rock middens have been offered; however, it is commonly accepted that their presence is directly linked to food processing. Subsistence remains recovered from burned rock middens include deer, acorns, and charred bulbs.

\section{Late Archaic}

The Late Archaic is characterized by Marcos, Castroville, Montell, Ensor, Frio, Fairland, and Darl points (Collins and Ricklis 1994). The number of sites and components reaches an all-time high in the Late Archaic period of Central Texas prehistory (Trierweiler et al. 1995). If site density is an accurate indicator of population density, it appears that the prehistoric population of Central Texas peaked at this time (Trierweiler et al. 1995). For the first time in the prehistory of Central Texas, cemeteries became part of the inventory of archaeological site types. Relatively large trade networks are indicated by the presence of marine shell in cemeteries, and corner tang knives have been recovered throughout Texas and beyond (Trierweiler et al. 1995). As for burned rock, "accumulating evidence supports continued and possibly increased use, throughout the Late Archaic" (Trierweiler et al. 1995:33). 


\section{Late Prehistoric Period}

The Late Prehistoric period in Central Texas spans approximately 800 years from $1150-350$ B.P. (Black 1989b). Two phases identified within this period are the Austin (1150-650 B.P.) and the Toyah (650-350 B.P.). The Late Prehistoric period is characterized by ceramic manufacture and changes in point style (Trierweiler et al. 1995). The presence of small arrow points (Edwards, Scallorn, and Perdiz) indicates a change to bow-and-arrow technology (Collins 1995).

The Austin phase is considered to be a continuation of the Late Archaic adaptation with an equal emphasis on both hunting and gathering (Collins and Ricklis 1994). Cemeteries containing marine shell artifacts remain in use during this time.

Based on the presence of bison remains and a tool assemblage comprised of Perdiz arrow points, large unifacial end scrapers, and beveled bifacial knives, Toyah phase sites reflect a shift in the exploitation of resources (Collins and Ricklis 1994). This tool assemblage is believed to be associated with the hunting and processing of bison. However, Toyah phase components such as the Mustang Branch site on Onion Creek (Collins and Ricklis 1994) and the Panther Springs and Hinojosa sites of South Texas demonstrate the continued importance of deer (Black 1989b). The manufacture of ceramics occurs sometime after A.D. 1300 (Trierweiler et al. 1995). Recent data indicate that burned rock midden technology was still in use during the Late Prehistoric period (Black et al. 1996; Houk and Lohse 1993; Tennis 1996; Trierweiler et al. 1995).

\section{Historic Period}

The European presence in Central Texas may have occurred as early as the mid-sixteenth century when the de Soto expedition traveled from northeast Texas, southwestward along the Balcones Escarpment as far as the New Braunfels area (Bruseth 1992). It was not until 1684, however, that the northern frontier of Tejas became an important consideration for Spain, brought about by the French presence in East Texas (Bannon 1979). Subsequently, several Spanish missions were constructed in the late-seventeenth and early- to mideighteenth centuries in east, central, and south Texas.

In addition to various factors of change induced by French and Spanish colonization efforts, the horse and European disease are cited as two important causes of the biological and social disruption of Native American groups indigenous to Texas (Collins and Ricklis 1994). By the mid- to late-nineteenth century, "the more than 11 millennia of Native American presence in the area came to an end" (Collins 1995:387).

\section{Methods}

A 100-percent-pedestrian survey was conducted of the $6.1-\mathrm{m}$ access road for a length of about $160 \mathrm{~m}$, and the 15.25-x-15.25-m building and monopole location (Figure 2). Four shovel tests were excavated to identify the presence of buried cultural remains within the access road. Two tests were placed in the area of the access to the north of Bob White's Express property fenceline, and two to the east of the fenceline within the access road (Figure 2). The shovel tests were excavated to a depth of $50 \mathrm{~cm}$.

Two backhoe trenches were excavated within the $15.25-\mathrm{x}-15.25-\mathrm{m}(50-\mathrm{x}-50-\mathrm{ft})$ building and monopole location. BT 1 was located one meter north of the proposed building location. This trench was $4 \mathrm{~m}$ long, $0.75 \mathrm{~m}$ wide, and $1 \mathrm{~m}$ in depth. BT 2 was located about $12 \mathrm{~m}$ southwest of the proposed monopole foundation. This trench was placed as close as possible to the monopole location, without disturbing the soil in the immediate area. BT 2 was $15 \mathrm{~m}$ long, $0.75 \mathrm{~m}$ wide, and $4 \mathrm{~m}$ deep.

Artifacts within the impact area were collected and returned to $\mathrm{CAR}$ for processing and analysis. Nondiagnostic artifacts outside the impact area were documented and left in situ. All administrative records, photographs, and laboratory records are on file at CAR. 
This page has been

redacted because it

contains restricted

information. 


\section{Results}

No artifacts were identified within the 15.25-x-15.25$\mathrm{m}$ construction area; however, a surface lithic scatter (41GU39) was identified within the access road easement. The survey was continued outside the easement to determine the limits of the scatter. We determined that the site covers an area approximately $95 \times 24.4 \mathrm{~m}$ along the main access corridor east of Bob White's Express property, and a 200-x-50-ft area to the north of this property which includes the remaining portion of the access road to the monopole foundation area.

Eighty artifacts were collected from the $975-\mathrm{m}^{2}$ area of the road easement, providing a density of one artifact per $12 \mathrm{~m}^{2}$. The assemblage consists of 58 core flakes, five biface thinning flakes, one piece of angular debris, four cores, one retouched flake, three biface fragments, two uniface fragments, two Guadalupe tools, one Gower point, and one triangular projectile point (Figure 3). Unworked chert nodules are present

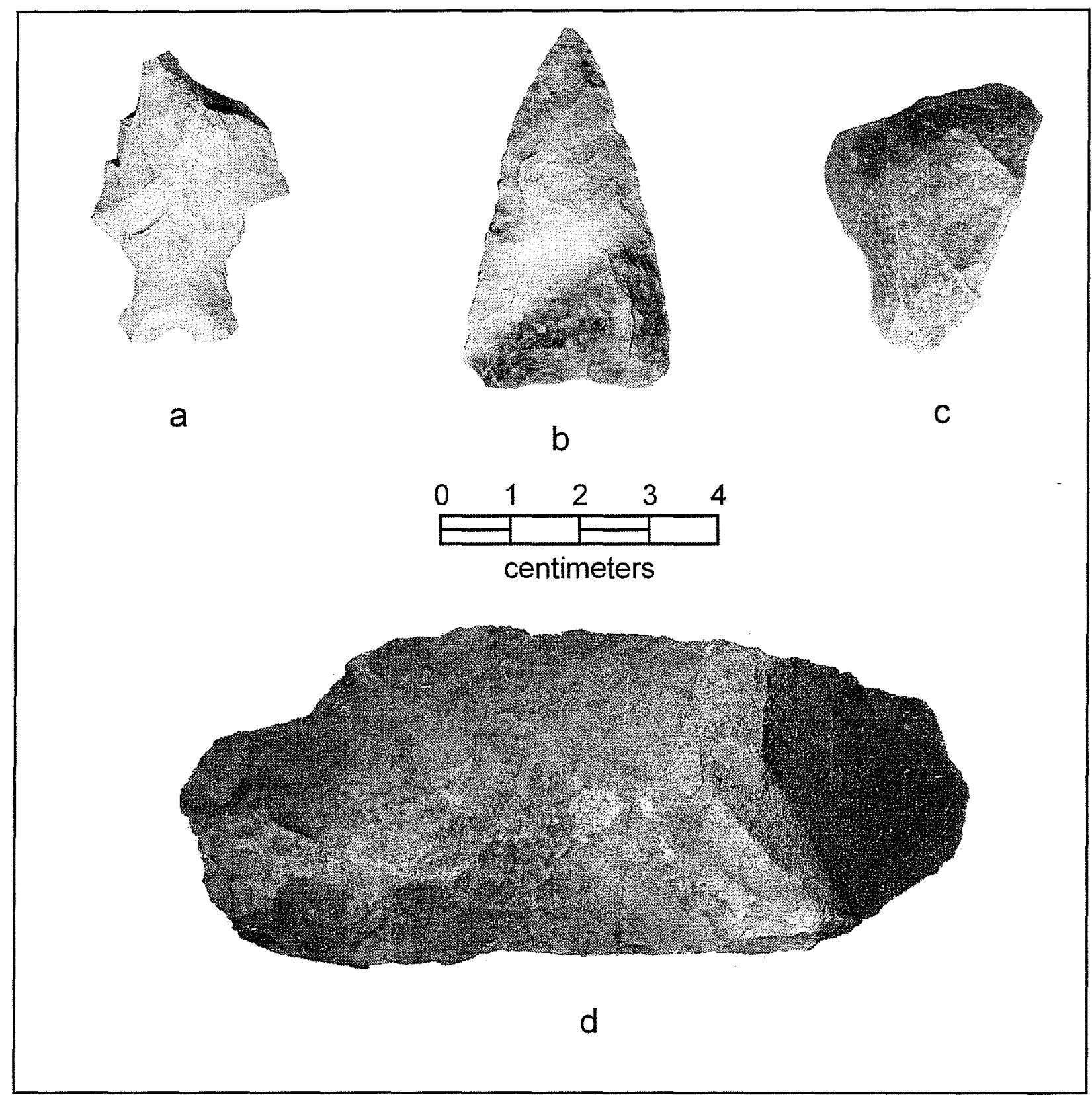

Figure 3. Artifacts from 4IGU39. a: Gower dart point; b: Triangular dart point; c: scraper; d: Guadalupe tool. 
in the plowed field, indicating that local raw materials were available.

Twenty percent of the core flakes do exhibit cortex, reflecting that secondary decortication occurred at the site. Tool production is also indicated by the presence of the several biface thinning flakes. The Gower point consists of a broken base, with multiple impact burinations on the distal end. In contrast, the triangular point is whole. The projectile points indicate that the site includes an Early Archaic component, but the triangular point could be classified as either an Early Archaic Triangular or a Tortugas point. The latter would reflect the presence of a Middle Archaic component at the site. Long-term plowing of the field has disturbed the site area, and local informants indicate that the site is often visited by collectors after being freshly plowed.

No cultural remains were identified during the excavation of BT 1 . The soil profile primarily consisted of a dark brown clay loam, with the upper $10 \mathrm{~cm}$ being disturbed by plowing (Table 1 ).

No cultural remains were observed in BHT 2. The soil profile exposed alluvial terraces deposits with a surface soil consisting of approximately one meter of a dark brown clay loam which was underlain with about three meters of a yellowish red clay loam (Table 2). Small gravels were present in this latter soil at a depth of $3.70 \mathrm{~m}$. The terrace is approximately 10 $\mathrm{m}$ above Cibolo Creek. The height and soil development suggest a Pleistocene age for the terrace.
No artifacts were recovered from any of the four shovel tests. The profiles of the shovel tests were similar to those exposed in the backhoe trenches, consisting mostly of a dark brown clay loam.

\section{Conclusions}

Archaeological site 41GU39 consists of a surficial scatter of lithic artifacts. They cluster in an arc around the periphery of Bob White's Express property. Although portions of Mr. White's property have been excavated for the placement of his building, discussions with the owner indicated that none of this material was deposited in the area of the site. It seems likely that construction destroyed any remains present on Mr. White's property, with site 41GU39 representing what is left. No subsurface remains were identified within any of the backhoe trenches or shovel tests, nor were any features identified at the site. A long-term history of plowing in the field has obviously disturbed the surficial deposits. In addition, the site is known among locals and has been collected over the years.

\section{Recommendations}

The subsurface survey of the monopole and support building locations did not locate any prehistoric artifacts or features in either backhoe trench. We recommend that the construction of the proposed

Table 1. BT 1 Soil Descriptions

\begin{tabular}{|c|l|}
\hline Depth (cm) & \multicolumn{1}{|c|}{ Description } \\
\hline $0-10$ & $\begin{array}{l}\text { dark brown (10 YR 4/3) clay loam, no structures, loose, friable, plow zone, abrupt lower } \\
\text { boundary. }\end{array}$ \\
\hline $10-46$ & $\begin{array}{l}\text { very dark grayish brown (10 YR 3/2), clay loam, medium-moderate angular blocky, weak } \\
\text { slicken sides, few small gravels, fragmented snail shell, clear smooth lower boundary }\end{array}$ \\
\hline $47-76$ & $\begin{array}{l}\text { dark brown (7.5 YR 3/4) clay loam, medium-moderate angular blocky, few small gravels, weak } \\
\text { slicken sides, common small insect burrows filled with very dark gray (10 YR 3/1), clay loam, } \\
\text { very few small gravels, few small CaCO nodules, manganese films that smear. }\end{array}$ \\
\hline $76-100+$ & $\begin{array}{l}\text { dark brown (7.5 YR 4/4) to strong brown }(7.5 \text { YR 4/6) clay loam, medium-moderate angular } \\
\text { blocky, moderate slicken sides, 10-15\% CaCO } 3 \text { nodules which are larger than above. }\end{array}$ \\
\hline
\end{tabular}


Table 2. BT 2 Soil Descriptions

\begin{tabular}{|c|c|}
\hline Depth (cm) & Descriptions \\
\hline $0-12$ & dark brown (10 YR 3/3) loam, no structure, few roots, abrupt lower boundary, plow zone. \\
\hline $12-22$ & $\begin{array}{l}\text { dark brown ( } 10 \text { YR } 3 / 3 \text { ) clay loam, weak slicken sides, medium-moderate an gular blocky, clear } \\
\text { smooth lower boundary, } 1-5 \% \mathrm{CaCO}_{3} \text {, small nodules. }\end{array}$ \\
\hline $22-80$ & $\begin{array}{l}\text { dark brown ( } 7.5 \text { YR 3/4) clay loam, with very dark grayish brown (10 YR } 3 / 2 \text { ) clay loam fill } \\
\text { in insect cracks and burrows, } 4-5 \% \mathrm{CaCO}_{3} \text { nodules (small), clear smooth lower boundary. }\end{array}$ \\
\hline $80-102$ & $\begin{array}{l}\text { reddish brown (5 YR 4/4) clay loam, medium-moderate angular blocky, slicken sides, } 1-5 \% \\
\text { small } \mathrm{CaCO}_{3} \text { nodules, very dark grayish brown }(10 \mathrm{YR} 3 / 2) \text { clay loam fill in insect burrows and } \\
\text { cracks, clear smooth lower boundary. }\end{array}$ \\
\hline $102-117$ & $\begin{array}{l}\text { yellowish red (5 YR 4/6) clay loam, slicken sides, medium-moderate angular blocky, increase } \\
\text { in } \mathrm{CaCO}_{3}(5-10 \%) \text {, larger size nodules. }\end{array}$ \\
\hline $117-157$ & $\begin{array}{l}\text { yellowish red ( } 5 \text { YR } 4 / 6) \text { clay loam, with moderate }\left(5-20 \mathrm{~mm} \text { ) soft } \mathrm{CaCO}_{3} \text { nodules, nodules are }\right. \\
\text { white ( } 5 \text { YR } 8 / 1 \text { ) to pink ( } 5 \text { YR } 7 / 4) \text {, gradual lower boundary. }\end{array}$ \\
\hline $157-370$ & same as above except for $\mathrm{CaCO}_{3}$ nodules increase to $50-75 \%$. \\
\hline $370-400+$ & reddish yellow (7.5 YR 7/6) clayey silt, with abundant rounded limestone gravels $(5-25 \mathrm{~mm})$. \\
\hline
\end{tabular}

monopole tower and associated building foundations will have no adverse affect on cultural resources. Although our testing did not extend as deep as the planned impact $(6.7 \mathrm{~m})$, the age of the deposits at the bottom of BT 2 precludes the possibility that cultural remains are more deeply buried.

The pedestrian survey of the access road encountered a light lithic scatter within the plow zone. This has been designated 41GU39. The surface scatter of lithic artifacts is apparently confined to the previously disturbed plow zone. We recommend that 41GU39 is not eligible for nomination to the National Register of Historic Places because it lacks appreciable depth and has been completely disturbed. We recommend that the construction of the access road to the monopole tower, which will involve placing approximately 25 $\mathrm{cm}$ of fill on the existing ground surface, will not adversely affect the cultural resources present. It is our overall recommendation that SWBW be allowed to proceed with the Retama/Selma project as planned because the project will have no adverse effect. SWBW is to be commended for their diligence in protecting our state's cultural resources. 


\section{References Cited}

Bannon, J. F.

1979 The Spanish Borderlands Frontier 1513-1821. University of New Mexico Press, Albuquerque.

Black, S. L.

1989a Environmental Setting. In From the Gulf Coast to the Rio Grande: Human Adaptation in the Central, South, and Lower Pecos Texas, edited by T. R. Hester, S. L. Black, D. G. Steele, B. W. Olive, A. A. Fox, K. J. Reinhard, and L. C. Bement, pp. 5-17. Research Series No. 33. Arkansas Archeological Survey, Fayetteville.

1989b Central Texas Plateau Prairie. In From the Gulf Coast to the Rio Grande: Human Adaptation in Central, South and Lower Pecos Texas, edited by T. R. Hester, S. L. Black, D. G. Steele, B. W. Olive, A. A. Fox, K. J. Reinhard, and L. C. Bement, pp. 17-38. Research Series No. 33. Arkansas Archeological Survey, Fayetteville.

Black, S. L., L. W. Ellis, D. G. Creel, and G. T. Goode (editors)

1996 Hot Rock Cooking on the Greater Edwards Plateau: Four Burned Rock Midden Sites in West Central Texas. Studies in Archaeology, review draft on file. Texas Archaeological Research Laboratory, The University of Texas at Austin.

Blair, W. F.

1950 The Biotic Provinces of Texas. Texas Journal of Science 2(1):93-117.

Bruseth, J. E.

1992 Artifacts of the De Soto Expedition: The Evidence from Texas. Bulletin of the Texas Archeological Society 63:67-97.

Collins, M. B.

1995 Forty Years of Archaeology in Texas. Bulletin of the Texas Archeological Society 66:361-400.

Collins, M. B., and R. A. Ricklis

1994 The Environmental Context. In Archaic and Late Prehistoric Human Ecology in the Middle Onion Creek Valley, Hays County, Texas, edited by M. B. Collins and R. A. Ricklis, 1:27-36. Studies in Archeology 19. Texas Archeological Research Laboratory, The University of Texas at Austin.

Houk, B. A., and J. C. Lohse

1993 Archeological Investigations at the Mingo Site, Bandera County, Texas. Bulletin of the Texas Archeological Society 61:193-247.

McKinney, W.

1981 Early Holocene Adaptation in Central and Southern Texas: The Problem of the Paleo-Indian-Archaic Transition. Bulletin of the Texas Archeological Society 52:91-120.

Prewitt, E. R.

1981 Cultural Chronology in Central Texas. Bulletin of the Texas Archeological Society 52:65-89. 
Ramsey, R. N., and N. P. Bade

1977 Soil Survey of Guadalupe County, Texas. United States Department of Agriculture, Soil Conservation Service, Washington, D.C.

Tennis, C. L.

1996 Archaic Land Use of Upper Leon Creek Terraces: Archaeological Testing in Northern Bexar County, Texas. Archaeological Survey Report, No. 234. Center for Archaeological Research, The University of Texas at San Antonio.

Trierweiler, W. N., G. L. Ellis, and J. M. Quigg

1995 Research Context for Site Testing. In NRHP Significance Testing of 57 Prehistoric Archaeological Sites on Fort Hood, Texas. Archaeological Resource Management Series Research Report No. 34. Vol 1:27-38. United States Army, Fort Hood.

Turner, E. S., and T. R. Hester

1993 A Field Guide to Stone Artifacts of Texas Indians. Second edition. Gulf, Houston.

Weir, F.

1976 The Central Texas Archaic. Ph.D. dissertation, Department of Anthropology, Washington State University, Pullman. 